\title{
Information Needs and Seeking Behavior of Assam University Library Users
}

\author{
Tuhina Choudhury (Deb Roy) \\ (Professional Assistant, Assam University, Silchar, Assam, India) \\ (Research Scholar, Department of Education, Assam University, Silchar, Assam, India)
}

\begin{abstract}
Information plays an important role in teaching, research and development. Moreover, information is growing in ever increasing volume and rate, in every field of human activity. During the recent decades, information needs have increased in volume and variety so also the information is necessary to be reprocessed and repackaged for different types of users so as to go with their needs. The researcher in this paper attempted to find out the information needs and seeking behavior of the users of Assam University Library, Silchar. Survey method was used and data was collected from 500 users of the library by administering questionnaires. The results of the study indicate that guidance and training is required for the use of library resources and services. Textbooks and periodicals are the most popular sources of information for the users. Library automation was found to be the need of the hour by most of the faculty members and research scholars.
\end{abstract}

Keywords- Information needs, Information seeking behavior, users, adequacy of collection, Information barrier constraints.

\section{Introduction}

Information is an indispensible resource for all human activities. As information is a valuable input for social development, only those who exploit information effectively will ultimately be in the lead [1]. Information has an important role in decision making, planning and every developmental activity. According to Hoshvosky and Marsey [2] "Information is a process which occur within human mind, when a problem and data for its solutions are brought into productive union". The term information need being an elusive term is difficult to define, isolate and measure. According to Wilson and Streat Field "Information need is a subjective relative concept existing only in the mind of experiencing individual." Krekalas defines information needs as "the recognition of the existence of uncertainty." The technological advancements and innovations that took place over the years have transformed libraries from mere store house of printed materials in to gateways to the world of information. Libraries are no longer stagnant reservoirs of books/documents. ICT has brought about radical changes in the way in which libraries gather, preserve and disseminate information. In a library or information centre, the users are the last link or the recipients of information in the communication cycle. Hence, understanding the user requirements is a fundamental prerequisite for libraries which aim at satisfying the information needs of the users which vary from user to user [3]. Information seeking behavior results from the recognition of some needs supposed by the users and may be defined as "the more common field of investigation, particularly concerned with the variety of methods people employ to discover" [4].

\subsection{Nature of the problem}

When a need is felt for something, action is taken in order to satisfy that need by resorting to various strategies. The same is the case for the satisfaction of information needs. The needs results in the demand of formal and informal sources of information. Voigt [5] clearly identified three types of information requirements. Later on a fourth type was added by other workers in the field. These are: Current approach, Everyday approach, Exhaustive approach, Catching-up or Brushing-up approach. Studying the needs and the seeking behavior helps the librarians and library professionals to come forward and satisfy their needs.

\subsection{Review of related literature}

While conducting a survey on the information needs \& use patterns of journals in economics in the University of Jammu Library system Raj Rani [6] found that journals were inadequate and only $10 \%$ of the users access the journals through Internet. The results of the studies carried out by Nazim \& Sarif [7] on Internet use in Beneras Hindu University showed that majority used internet facility through the University for Research Work. Slow speed, high internet charges, lack of training and lack of organized information are 
some of the factors that affect the use of internet. Two similar studies on information seeking behavior of agricultural scientists by Keshava \& Savanur [8] and Singh \& Satija [9] revealed that in both the cases users were satisfied with the services and facilities of the library and they highly depend on the library collections. Choukande [10], Fatima, N \& Ahmad, N [11], Devendra Kumar[12], Mahajan [13], Ray \& Balsy [14] and Jayaram, Subramanian \& Krishnaswamy[15] conducted similar studies in finding information needs \& seeking behavior of users of different university \& college libraries. In all these studies the researchers attempted to highlight the adequacy of the collection and services with the research needs of the users of these educational institutions.

Among the reviewed studies carried abroad, Junni[16] studied the internet effect on students seeking information for their Master's thesis. The main problem reported by the students was lack of training in information seeking, and the abundance of irrelevant information on the internet. A significant difference between the information needs of faculty members in private and public universities were found in the study of Nnadozie \& Nnadozie [17]. The major obstruction to information access was observed to be the lack of current and relevant sources. Tahir, Mahmood \& Shafique[18] and Bhatti[19] in their study of information seeking behavior of arts and humanities teachers of the University of Punjab, Lahore, Pakistan and faculty members at the Islamia University of Bhawalpur found that majority of users preferred consultation with subject experts in gathering information.

\subsection{Purpose of the study}

The main purpose of the study is to explore the nature and types of information needs and seeking behavior of the users of Assam University Library, Silchar. The other objectives are to find the adequacy in collection and services and study the different information barrier constraints faced by the users of the library.

\subsection{Contribution of the paper}

Studying the information needs and seeking behavior of the users of Assam University Library, Silchar depicts a clear picture of the adequacy of the collection and the services of the library. Further it throws light on the extent of use of the library resources and services. Such type of study helps in the development of quality collection of the library. Studying the constraints faced by the users in gathering information helps in improving the services and sources of the library.

\section{Library System of Assam University, Silchar}

Assam University, Silchar, a Central University was set up by an Act of parliament proclaimed in 1989 and enforced by a Notification of the Government of India in January 1994. In 2008 the University has been accredited by NAAC with Grade B with a CGPA of 2.85 . The main campus of the University is 23 K.M. away from Silchar city, the tea capital of South Assam. The university campus at Silchar is spread over an area of about 600 acres on which there are 16 different Schools of Studies and 34 post Graduate departments and 3 interdisciplinary centers including School of Technology. In addition Central Instrumentation Laboratory, CIL has also been established in the University. The institution provides the most developed facilities to students coming from different parts of the country and abroad [20].

Assam University, named as Rabindra Library was started with the establishment of the University in the year 1994 as a central organization for meeting the requirements of the academic community of the University. The Central Library of Assam University has been shifted to its new permanent central Library cum Computer Centre building since $21^{\text {st }}$ January 2006.The library is situated at the centre of the University Campus with all the Schools of Studies around it for easy access of the users from every department. The total plinth area of the new building is 38,700 square feet with fencing around it. The users of Assam University Library include undergraduate and postgraduate students of different subjects, faculty members, technical and non- teaching staff, research students working for M.phil or PhD degree, professors and experts guiding research projects and managing research activities of the University, members of the various academic and executive bodies of the University, the University management and visiting fellows, scholars and others. The University Library at present has a stock of total 1, 09,331books (2012) out of which 11,373 books have been acquired during 2010-11. The total expenditure incurred for purchase of books came to Rs. 1, 03, 15,812 /- only. The Library subscribed/renewed 96 Indian and 89 foreign Journals during 2010-11 .Besides these, 18 Newspapers and 12 Popular Magazines have also been subscribed during this period. The Library has also received 60 nos. of $\mathrm{PhD} / \mathrm{M}$.Phil/Master degree Theses and Dissertations and Project Reports from the Examination Branch of Assam University. The Library also received 555 Books, 102 Journals, 20 Reports, 4 Conference Proceedings, 98 Newsletters and 240 Reprints from American Centre Library as Gift/Donated items during 2010-2011 [21].

The following are the services offered by the Assam University Library: 
- Lending and Readers Services.

- Proactive Information Services.

- Reference and Research Services.

- Reprographic Services.

- Internet and On-Line E-Resource Service.

- Newspaper, Magazine and Journals Service, Videos.

- On-Line Public Access Catalogue.

- Special Category Membership Services.

- Information Services.

- Other Activities.

Assam University in its Library Committee meeting approved the subscription of Databases Services of DELNET from 2003 onwards and the facilities of accessing Digital Information Resources, Bibliographical and other Databases and Inter Library Loan Services of DELNET. INFLIBNET Center has selected Assam University Library as one of the participating Libraries for automation and networking of Library services during 1996-97. During, July - August 2000 SOUL software were installed in Assam University Library by INFLIBNET officials along with training of the Library professionals. On $15^{\text {th }}$ August, 2001 OPAC facility was inaugurated and the service were made operational for the Faculty Members, Students and Staff. In July, 2011 a week long in-house training was organized by Assam University Library in collaboration with INFLIBNET for the installation of SOUL 2.0. From April 2013, database creation work is under progress. Under UGC-INFONET e-journals Consortium, Assam University Library users are also getting On-Line access to $5000+$ e-journals covering various International Journals and databases over Internet. The faculty members, research scholars and students are widely utilizing these facilities for their academic endeavour.

JCCC is J-Gate Custom Content Consortia for a group of homogeneous consortia members, and JCCC-INDEST is J-Gate Custom Content for the Indian National Digital Library in Sciences and Technology (INDEST), a consortium set up by the Ministry Of human Resource Development, Government of India, on the recommendation made by the Expert Group appointed by its under the chairmanship of Prof N. Balakrishnan. Assam University Library has been identified as one of the Resource Centre under JCCC programme. Document delivery services are being provided by Assam University Library under JCCC@INDEST-AICTE.

\section{Methodology}

The Methodology adopted to find out the information needs of the users of Assam University Library is the survey method and questionnaire was used as the tool for data collection. The technique used by the researcher is the random sampling technique. A total of 500 questionnaires were distributed randomly in the different departments as well as among the users who visited the library, over a period of eight months during the year 2009-2010. 470 questionnaires duly filled up were returned to the researcher resulting to $94 \%$ response rate.

\subsection{Design of questionnaire}

The questionnaire (Choukhande, 2008) has been referred to and designed accordingly. The questions include both factual and opinion questions. Most of the questions are close-ended or structured in nature. The questionnaire consisted of 5 sections or parts.

(I) General Information

(II) Information needs of users

(III) Information gathering behavior of users

(IV) Constraints faced by the users

(V) Suggestions.

The rating scale in the questionnaire used is a two point scale of 'yes' or 'no' and 'satisfactory' or 'unsatisfactory'. A three point scale of 'adequate', 'inadequate' or 'partially adequate' is also used in some questions. More than three options were provided for a few questions to get appropriate answers.

\section{Data Analysis And Interpretations}

On the basis of filled up questionnaires the data has been analyzed and tabulated. The results are interpreted and shown in tabular and graphical representation. Percentage technique has been adopted for data analysis. As maximum questionnaires were distributed among the users within the library premises, the above table also depicts the percentage distribution of different categories of users visiting the library. 


\subsection{General information}

\subsubsection{Category wise users and their responses}

Out of 500 questionnaires distributed, 470 filled up questionnaires were received resulting to a $94 \%$ response rate. Among these 470 respondents total number of Faculty Members was 85, Non-Teaching Staff 27, Ph. D Scholars 65, M.Phil Students 32, Undergraduate Students 117 and Post Graduate Students 144.

Table 1.1 User categories and percentage of their responses

\begin{tabular}{|c|c|c|c|}
\hline SI. No. & Types of users & No. of responses received & $\begin{array}{c}\text { Percentage } \\
\text { distribution }\end{array}$ \\
\hline 1. & Faculty Members & 65 & $13.83 \%$ \\
\hline 2. & Non-Teaching Staff & 27 & $5.74 \%$ \\
\hline 3. & Ph.D Scholars & 85 & $18.09 \%$ \\
\hline 4. & M.Phil Students & 32 & $6.81 \%$ \\
\hline 5. & Undergraduate Students & 117 & $24.90 \%$ \\
\hline 6. & Post Graduate Students & 144 & $30.64 \%$ \\
\hline & Total & $\mathbf{4 7 0}$ & $\mathbf{1 0 0 \%}$ \\
\hline
\end{tabular}

\section{Source: Primary Data}

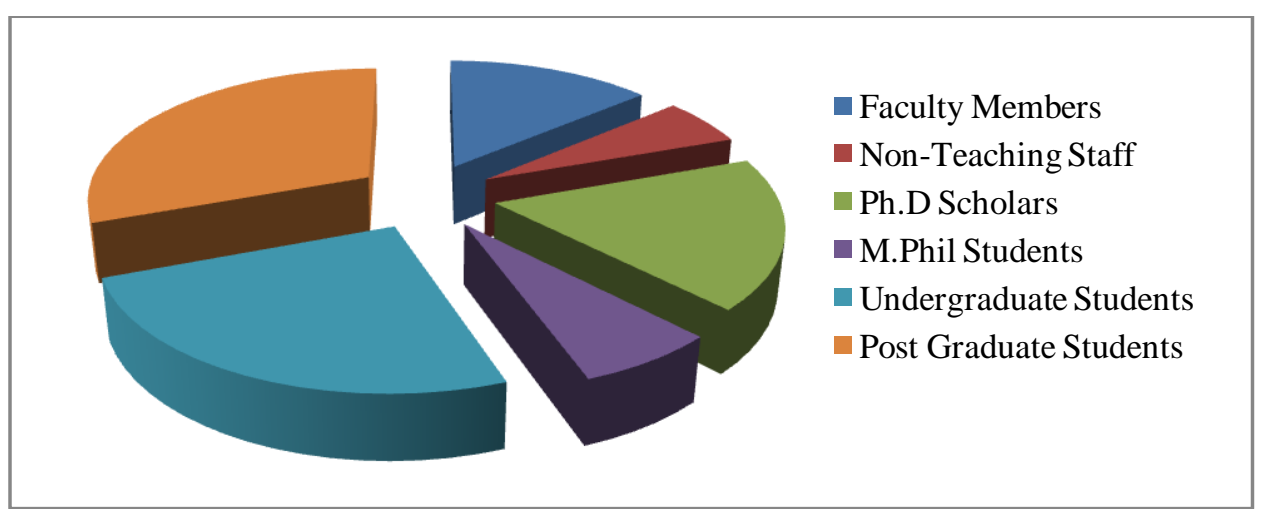

Fig.1.1 showing category-wise percentage distribution of questionnaires

Table 1.1 and Fig.1.1 clearly shows that the maximum responses were received from the post graduate students; their response percentage being $30.64 \%$ followed by under graduate students whose response percentage is $24.9 \%$. The lowest responses received were from the non-teaching staff, percentage of response being $5.74 \%$ followed by M.Phil Students, their response rate being $6.81 \%$. The response rate of Faculty Members and Ph.D Scholars were found to be $13.83 \%$ and $18.09 \%$ respectively.

\subsubsection{Age-wise distribution of users}

The Under Graduate Students as well as Post Graduate Students come under the age group of 15-25 years. Under the age group of 26-35 years are mostly Ph.D Scholars, M.PhilStudents. Also faculty members and nonteaching staffs too come under this age group. The users under 36-45 years of age group are mainly faculty members and non teaching staff but there are Ph.D Scholars too under this age group. Faculty members and nonteaching staff fall under the age group of 46-55 years of age and there may be Ph.D Scholars too. From the age 55 years onward are mainly Faculty members and nonteaching Staff.

Table 1.2 Age-wise percentage distribution of users

\begin{tabular}{|l|l|l|}
\hline Age & Numbers & Percentage \\
\hline $15-25$ & 261 & $55.53 \%$ \\
\hline $26-35$ & 110 & $23.40 \%$ \\
\hline $36-45$ & 56 & $11.91 \%$ \\
\hline $46-55$ & 31 & $6.60 \%$ \\
\hline $55---$ & 12 & $2.55 \%$ \\
\hline Total & $\mathbf{4 7 0}$ & $\mathbf{1 0 0 \%}$ \\
\hline
\end{tabular}

Source: Primary Data 


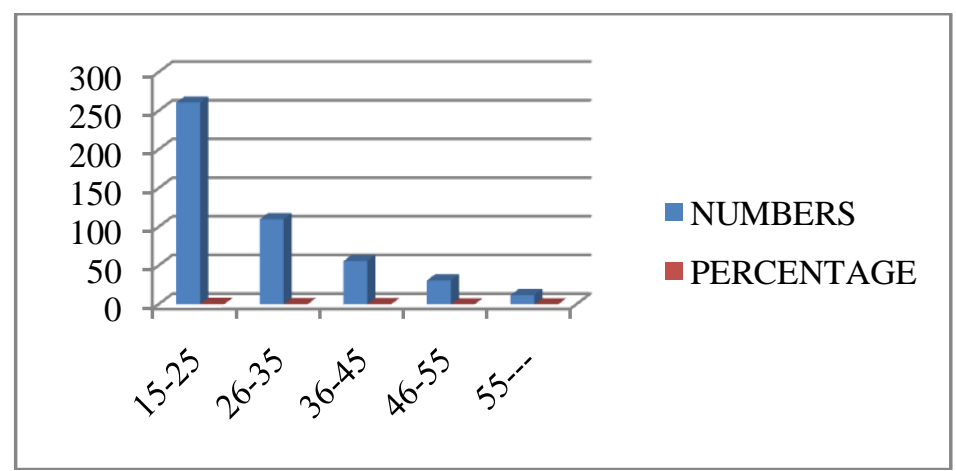

Fig.1.2 showing age-wise percentage distribution of users

Maximum responses were obtained from the under graduate and post graduate students which is $55.53 \%$. Next are the respondents under the age group of 26-35 years, comprising of Ph.D Scholars, M.Phil Students Faculty Members and Nonteaching Staff showing a percentage response of 23.40\%. The respondents under the age group of 36-45 years, 46-55 years and 55- onwards shows percentage response of $11.91 \%, 6.60 \%$ and $2.55 \%$ respectively.

\subsubsection{Sex-wise distribution of respondents:}

The male and female respondents' percentage were calculated. The following table shows the percentage distribution of male female respondents.

Table 1.3 Sex-wise percentage distribution of respondents

\begin{tabular}{|l|c|c|}
\hline Sex & No. of respondents & Percentage distribution \\
\hline Male & 217 & $46.17 \%$ \\
\hline Female & 253 & $53.83 \%$ \\
\hline Total & $\mathbf{4 7 0}$ & $\mathbf{1 0 0 \%}$ \\
\hline
\end{tabular}

Source: Primary Data

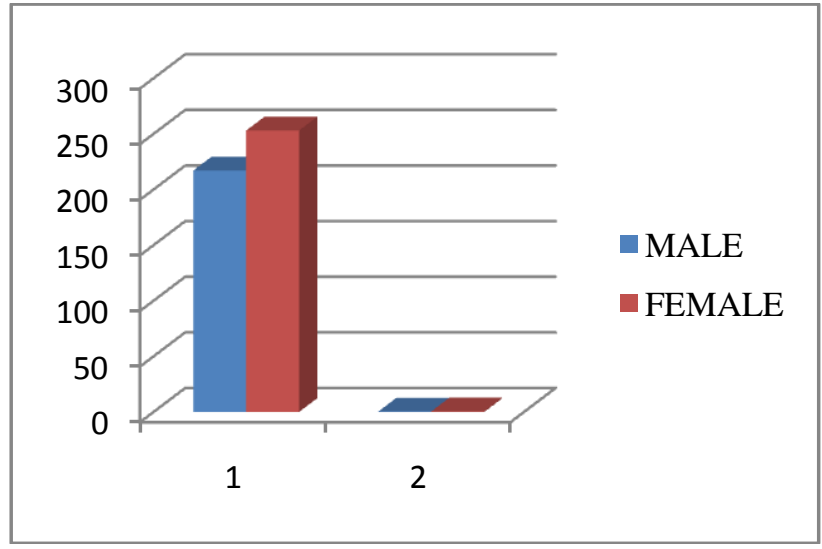

Fig.1.3 showing sex-wise percentage distribution of respondents

Table 1.3 and Fig.1.3 clearly depicts the male female distribution of respondents. The percentage of female respondents is found to be $53.83 \%$ and percentage of male respondents is $46.17 \%$. Thus female respondents are found to be more than male respondents.

\subsection{Information needs of users}

The information needs of specific users are not directly observable and are complex in nature. Hence it is very important to study the user's needs and interests so as to design information system effectively.

\subsubsection{Extents of study/research/teaching needs met by the collection of the Library}

In order to understand how far the needs of the users are met by the collection of the library a three point scale question of adequate, partially adequate and inadequate was structured. The analysis is tabulated in Table 2.1. 
Table 2.1 Extents of study/research/teaching needs met by the collection of the library

\begin{tabular}{|c|c|c|c|c|c|}
\hline Sl.no. & Collection of the library & Adequate & $\begin{array}{l}\text { Partially } \\
\text { adequate }\end{array}$ & Inadequate & Total \\
\hline 1 & Text Book & $\begin{array}{c}165 \\
(35.11 \%)\end{array}$ & $\begin{array}{c}186 \\
(39.57 \%)\end{array}$ & $\begin{array}{c}119 \\
(25.32 \%)\end{array}$ & 470 \\
\hline 2 & Encyclopedia & $\begin{array}{c}210 \\
(44.68 \%)\end{array}$ & $\begin{array}{c}231 \\
(49.15 \%)\end{array}$ & $\begin{array}{c}29 \\
(6.17 \%)\end{array}$ & 470 \\
\hline 3 & Dictionaries & $\begin{array}{c}189 \\
(40.21 \%)\end{array}$ & $\begin{array}{c}176 \\
(37.45 \%)\end{array}$ & $\begin{array}{c}105 \\
(22.34 \%)\end{array}$ & 470 \\
\hline 4 & Periodicals & $\begin{array}{c}167 \\
(35.53 \%)\end{array}$ & $\begin{array}{c}216 \\
(45.96 \%)\end{array}$ & $\begin{array}{c}87 \\
(18.51 \%)\end{array}$ & 470 \\
\hline 5 & Thesis/Dissertations & $\begin{array}{c}125 \\
(26.60 \%)\end{array}$ & $\begin{array}{c}178 \\
(37.87 \%)\end{array}$ & $\begin{array}{c}167 \\
(35.53 \%)\end{array}$ & 470 \\
\hline 6 & Reference Books & $\begin{array}{c}138 \\
(29.36 \%)\end{array}$ & $\begin{array}{c}196 \\
(41.70 \%)\end{array}$ & $\begin{array}{c}136 \\
(28.94 \%)\end{array}$ & 470 \\
\hline 7 & Internet & $\begin{array}{c}65 \\
(13.83 \%)\end{array}$ & $\begin{array}{c}137 \\
(32.09 \%)\end{array}$ & $\begin{array}{c}268 \\
(57.02 \%)\end{array}$ & 470 \\
\hline 8 & E-Journals & $\begin{array}{c}44 \\
(9.36 \%)\end{array}$ & $\begin{array}{c}97 \\
(20.64 \%)\end{array}$ & $\begin{array}{c}329 \\
(\mathbf{7 0 \%})\end{array}$ & 470 \\
\hline
\end{tabular}

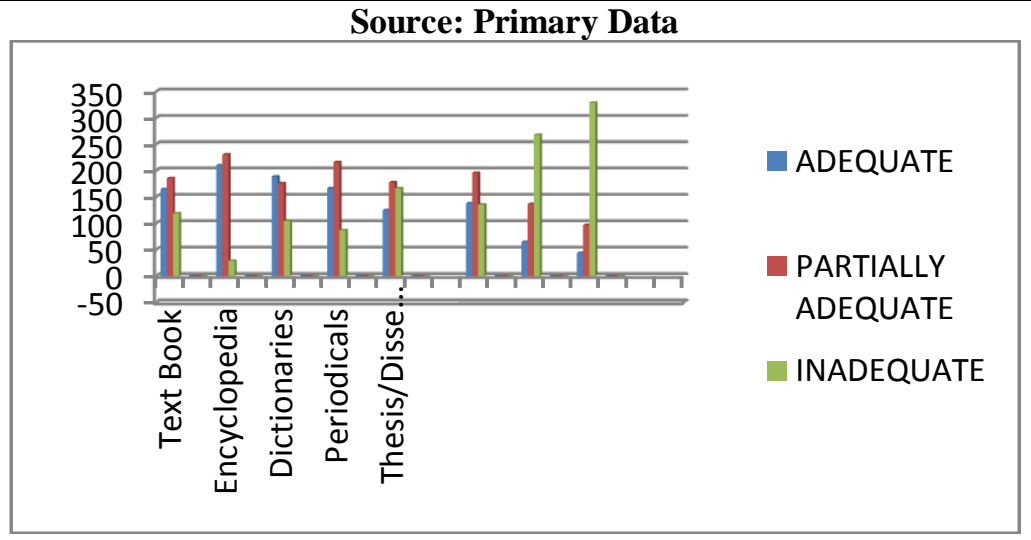

Fig. 2.1 showing extent of information needs of the users met by the collections of the library

Table 2.1 \& Fig. 2.1 indicates $35.11 \%$ users marked text books as adequate, $39.57 \%$ as partially adequate and $25.32 \%$ as inadequate. In case of Encyclopedia $44.68 \%$ of the users found the collection to be adequate, $49.15 \%$ to be partially adequate and $6.17 \%$ to be inadequate. The library has a good collection of Encyclopedias as reflected by the average responses of the users. In case of dictionaries $40.21 \%$ of the respondents marked as adequate, $37.45 \%$ partially adequate and $22.34 \%$ inadequate. It is found that standard dictionaries are available in the library but specialized dictionaries related to different subjects are more required and hence dictionaries were found partially adequate and inadequate for average number of users. Periodicals play a great role in imparting up to date information as well as retrospective information, but the escalating price of periodicals especially the foreign ones has limited the subscription of this important information source. This is evident from the responses of the users where $35.53 \%$ of them have marked periodicals as adequate, $45.96 \%$ as partially adequate and $18.51 \%$ as inadequate. Theses/dissertations are marked by $26.6 \%$ of users as adequate, $37.87 \%$ as partially adequate and $35.53 \%$ as inadequate, the marking being average in all the three cases. While purchasing books, budget is allocated for each department and also for Central Library which comes under the General Collection. Reference Books fall under this category along with Encyclopedia and Dictionaries. 29.36\% of the users marked reference books as adequate, $41.7 \%$ as partially adequate and $28.94 \%$ as inadequate. In today's world of information communication Technology, Internet plays an important role. Assam University Library also provides Internet Services to its users. Thus $13.83 \%$ users found Internet facility adequate, $32.09 \%$ partially adequate and $57.02 \%$ inadequate. The probable reason behind such responses may be due to the incessant power cut and poor internet service in this part of Barak Valley. E-Journals are also an important information source available online. Through UGC-INFONET Consortia Assam University Library has access to 5000+ ejournals. Also through membership of DELNET and DeLCON more e-journals and online databases can be accessed. Inspite of these $9.36 \%$ users marked e-journals as adequate, $20.64 \%$ as partially adequate and $70 \%$ as inadequate.

\subsubsection{Use of electronic sources of information}

Users were asked whether they used electronic sources of information. If yes then they were asked to put tick marks to the options of electronic sources given in the questionnaire. 
Table 2.2 Electronic sources of information and their use

\begin{tabular}{|c|c|c|c|}
\hline Sl. No. & Electronic sources & Number of users & Percentage \\
\hline 1. & Internet & 312 & $66.38 \%$ \\
\hline 2. & E-mail & 216 & $45.96 \%$ \\
\hline 3. & Online databases & 15 & $3.19 \%$ \\
\hline 4. & CD-Rom & 145 & $30.85 \%$ \\
\hline 5. & Audio-visual sources & 470 & $100 \%$ \\
\hline
\end{tabular}

\section{Source: Primary Data}

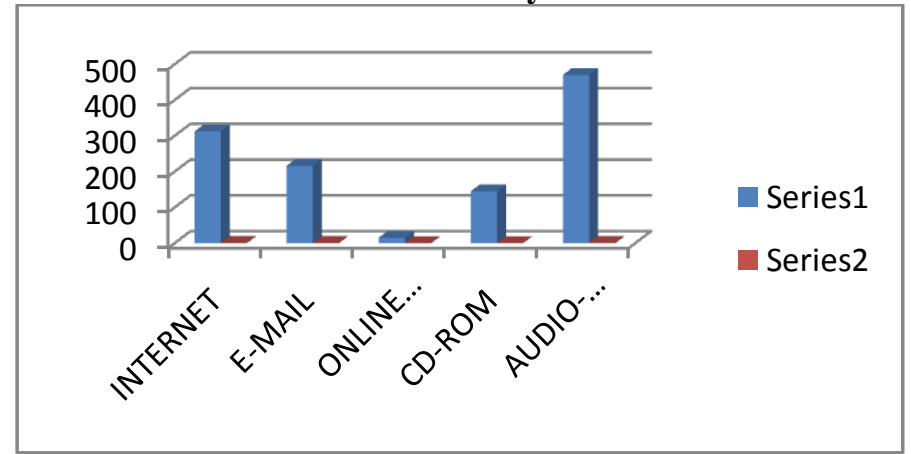

Fig.2.2showing the use of electronic information sources by the respondents

The above table and fig. clearly depicts that use of Audio-Visual sources are maximum (100\%) and it is obvious that television is the most popular audio-visual source. Next to audio-visual source is the Internet $(66.38 \%)$ which has gained popularity for accessing any type of information within a very short time through various search engines. This is followed by E-Mail (45.96\%) which is mostly used by Faculty members and research scholars for exchanging information. CD- ROMsare also used by the users $(30.85 \%)$ for storing information and Data. The least use is of Online Databases (3.19\%), the reason being that online Databases have to be subscribed for accessing. Being member of DELNET and DeLCON consortia Assam University can access their online data bases. Also there are two online databases subscribed by the library for the Department of Business Administration. So in all these cases these have to be accessed only within the university campus. Also lack of awareness may be another reason for less use of this electronic information source.

\subsubsection{Use of internet facility of the library}

Respondents were asked to answer in the two point scale of yes or no regarding the use of internet facility of the university library.

Table 2.3Use of internet facility of the library

\begin{tabular}{|l|l|l|l|l|}
\hline $\begin{array}{l}\text { Use of internet } \\
\text { Facility }\end{array}$ & Yes & No & $\begin{array}{l}\text { Percentage of } \\
\text { Positive responses }\end{array}$ & $\begin{array}{l}\text { Percentage of } \\
\text { negative } \\
\text { responses }\end{array}$ \\
\cline { 2 - 5 } & 119 & 351 & $25.32 \%$ & $74.68 \%$ \\
\hline
\end{tabular}

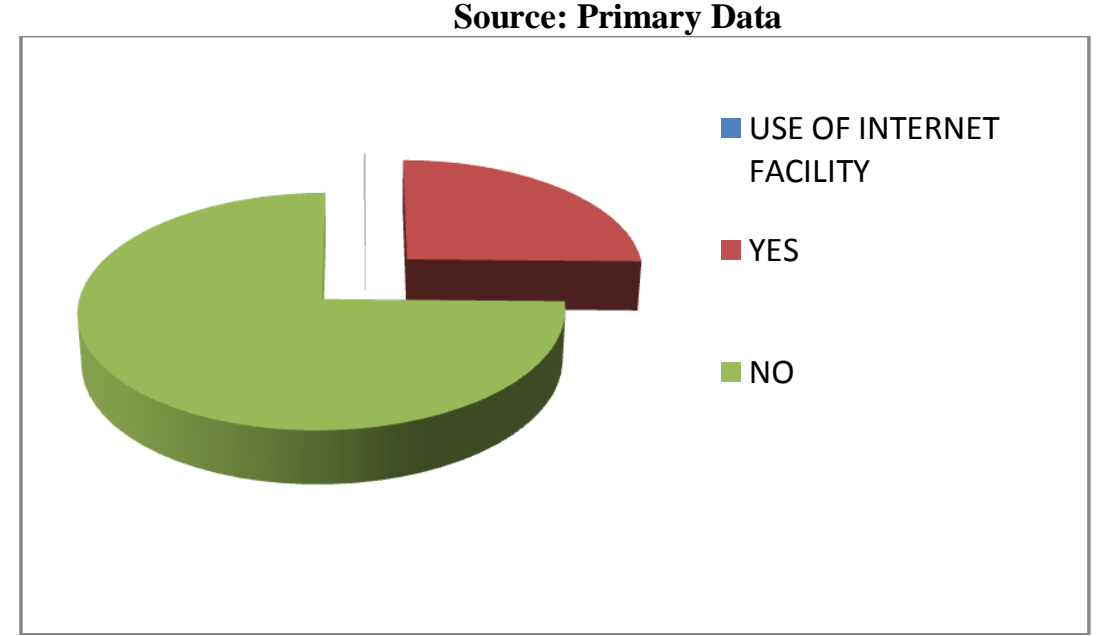

Fig.2.3 showing the use of internet facility of the library

From Table 2.3 and Fig.2.3 it is quite evident that the use of internet facility of the library is very low. Maximum faculty members and research scholars have their own internet connectivity and even some students also have the same at their home. The other reasons behind the low use are the constant powercut and poor internet service in this part of the valley. Of course things have improved since the time of survey 
(2009-2010) as the library has acquired its own generator and the internet service has also improved since then.

\subsubsection{Success in getting material required from different sources}

A three point rating scale of mostly, partially and never is used in this case where the respondents were asked to rate how far they are successful in obtaining the required information.

Table 2.4 Successes in getting material required from different information sources

\begin{tabular}{|c|l|c|c|}
\hline Sl. no. & Rating & No .of users & Percentage \\
\hline 1. & Mostly & 137 & $29.15 \%$ \\
\hline 2. & Partially & 244 & $51.91 \%$ \\
\hline 3. & Never & 89 & $18.94 \%$ \\
\hline
\end{tabular}

Source: Primary Data

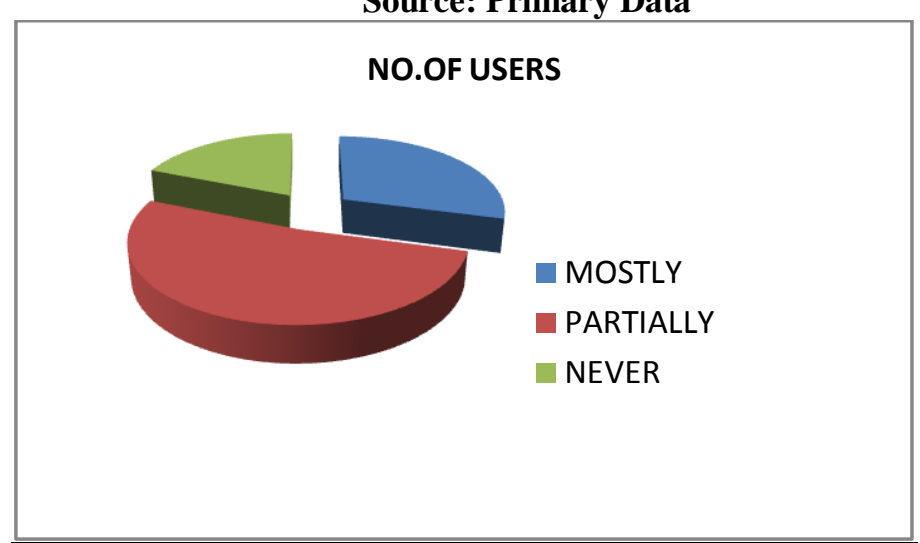

Fig.2.4 showing the success rating of the users in getting information from different information sources

From the above Table and Fig. it is clear that $29.15 \%$ of the users are successful in getting relevant information, $51.91 \%$ are partially successful and $18.94 \%$ of the respondents fail to get relevant information from the information sources available in the library.

\subsection{Information seeking behavior}

In order to fulfill the information needs, the user actively undergoes the information seeking process. Hence after analyzing information needs, it is necessary to analyze and interpret the data, so as to find out the information seeking behavior of the users.

\subsubsection{Frequency of visit to the library}

Respondents were given 5 categories to mark the frequency of their visit to the library.

Table 3.1 Frequency of visit to the library

\begin{tabular}{|c|c|c|c|}
\hline $\begin{array}{c}\text { Sl. } \\
\text { No. }\end{array}$ & Category & No. of responses & $\begin{array}{l}\text { Percentage of } \\
\text { responses }\end{array}$ \\
\hline 1. & Almost daily & 75 & $15.96 \%$ \\
\hline 2. & Twice a week & 136 & $28.94 \%$ \\
\hline 3. & Once in a week & 145 & $30.85 \%$ \\
\hline 4. & Fortnightly & 88 & $18.72 \%$ \\
\hline 5. & Rarely & 26 & $5.52 \%$ \\
\hline & Total & $\mathbf{4 7 0}$ & $\mathbf{1 0 0 \%}$ \\
\hline
\end{tabular}

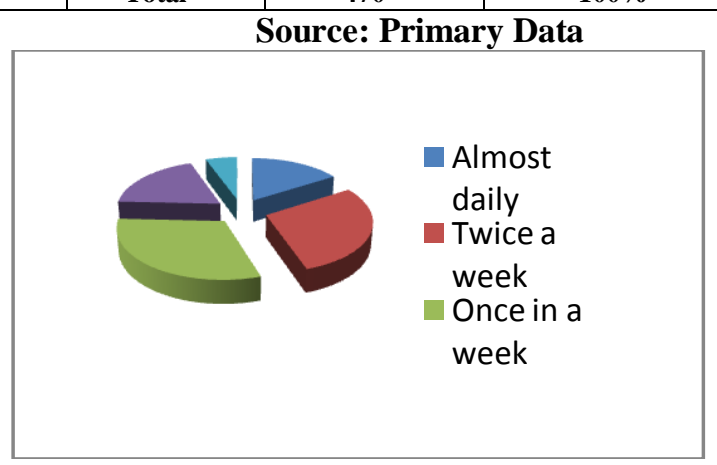

Fig3.1 showing user's frequency of visit to the library 
Table 3.1 and Fig.3.1 indicates the frequency of visit of the respondents to the library and the percentage of their responses. It is quite evident that maximum respondents visit the library once a week, their percentage being $30.85 \%$. Next is their visit twice a week, the percentage of respondents being $28.94 \%$. The percentage of respondents who visit the library fortnightly is $18.72 \%$. The respondents who visit the library almost daily is less and their percentage is $15.96 \%$. The library is visited rarely by $5.52 \%$ of the total respondents.

\subsubsection{Purpose of visit to the Library}

Frequency of the visit to the library does not indicate the nature and purpose of visit by its users. Keeping this aspect in mind, the respondents were asked to indicate the purpose of their visit to the library.

Table 3.2 Purpose of visit to the library

\begin{tabular}{|c|c|c|c|}
\hline $\begin{array}{c}\text { Sl. } \\
\text { No. }\end{array}$ & Purpose of visit & No. of responses & $\begin{array}{c}\text { Percentage of } \\
\text { responses }\end{array}$ \\
\hline 1. & Study/teaching/research & 393 & $83.62 \%$ \\
\hline 2. & To locate information from documents & 286 & $60.85 \%$ \\
\hline 3. & To search information from e-resources & 37 & $7.87 \%$ \\
\hline 4. & To borrow books & 461 & $98.09 \%$ \\
\hline 5. & To spent leisure time & 24 & $5.11 \%$ \\
\hline
\end{tabular}

\begin{tabular}{|l|l|}
\hline Source: Primary Data & $\begin{array}{l}\text { Study/teaching/resear } \\
\text { ch } \\
\text { To locate information } \\
\text { from documents } \\
\text { To search information } \\
\text { from e-resources } \\
\text { To borrow books }\end{array}$ \\
\end{tabular}

Fig.3.2 showing percentage of responses for the purpose of visit to the library

The above table and fig. shows that $461(98.09 \%)$ respondents visit the library to borrow books, $393(83.62 \%)$ for study/teaching/research purpose, $286(60.85 \%)$ to locate information from documents, 37 $(7.87 \%)$ to search information from e-resources and only $24(5.11 \%)$ respondents visit the library to spent leisure time. Thus most of the users visit the library for borrowing books, for study/ teaching/research purpose and to locate information from documents. Most of the respondents indicated more than one purpose for visiting the library. The number of respondents for searching information from e-resources and spending leisure time is very limited.

\subsubsection{Use of library services}

The prime function of any library is to provide efficient services to its users. Users' awareness about the services provided by the library is essential for effective use of its collection. Respondents were asked regarding the awareness and use of the various services provided by the library.

Table 3.3 Awareness and utilization of services of the library

\begin{tabular}{|l|c|c|c|c|}
\hline \multirow{2}{*}{$\begin{array}{l}\text { Sl. } \\
\text { No. }\end{array}$} & Library services & \multicolumn{2}{|c|}{ Number of responses } & $\begin{array}{c}\text { Percentage } \\
\text { of use }\end{array}$ \\
\cline { 3 - 4 } & & Awareness & Use & \\
\hline 1. & Circulation Service & 470 & 461 & $98.09 \%$ \\
\hline 2. & Reference Service & 235 & 189 & $40.21 \%$ \\
\hline 3. & Reprographic Service & 470 & 356 & $75.74 \%$ \\
\hline 4. & Internet Service & 470 & 119 & $25.32 \%$ \\
\hline 5. & $\begin{array}{c}\text { Selective Dissemination of } \\
\text { Information Service }\end{array}$ & 20 & 0 & 0 \\
\hline 6. & Current Awareness Service & 13 & 0 & 0 \\
\hline 7. & Newspaper, Magazine and Journals & 470 & 281 & $59.79 \%$ \\
\hline 8. & Service & 9 & 0 & 0 \\
\hline
\end{tabular}




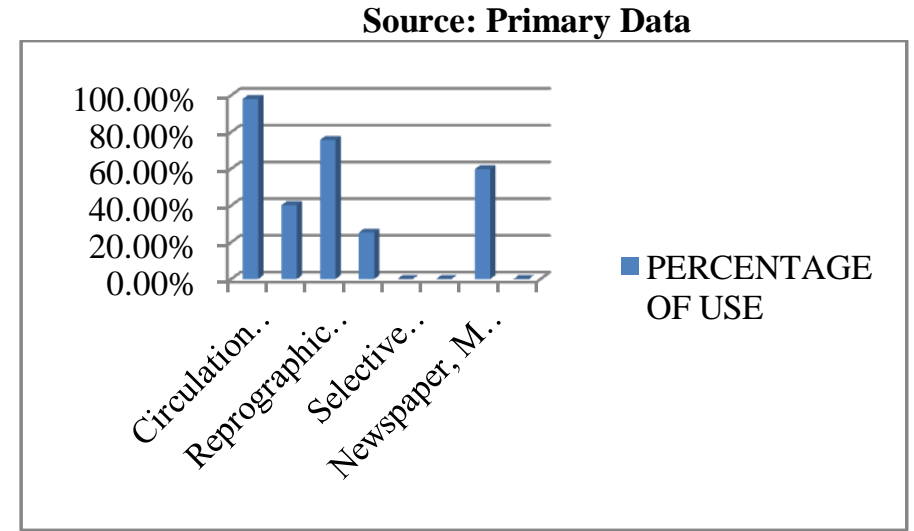

Fig.3.3 showing percentage of use of library services

Table 3.3 and Fig.3.3 (A) \& (B) clearly depicts the awareness and use of library services along with the percentage of their use. Out of 470 respondents, 470 of them are aware of circulation service and 461 use the service resulting to $98.09 \%$ of use. Analysis shows that all the respondents are aware of reprographic service and $356(75.74 \%)$ of them use the service. All the respondents are found to be aware of Newspaper, Magazines and Journal service and $281(59.79 \%)$ make use of this service. It is found that 235 respondents are aware of reference service and $189(40.21 \%)$ use this service. Among the 470 respondents only 119 (25.32\%) use Internet service of the library. Selective dissemination of Information is based on the concept of personal service where user's information needs are matched with the information available in the library. Analysis shows that only 20 respondents are aware of this service but not a single of them used this service. Current Awareness Service is the best way to bring the resources of a library to the notice of its users. 13 respondents are found to be aware of this service but its use is nil. Document Delivery Service is being provided by Assam University Library under JCCC@INDEST-AICTE (J-Gate Custom Content for the Indian Digital Library in Science and Technology which is a consortium set by the Ministry of HRD, Govt. of India. Only 9 respondents are found to be aware of this service but no one ever used this service.SDI, CAS and Document Delivery service are not at all used, the reason being that these services are not provided by the library in a large scale and there is no publicity of these services and hence most of the users remain unaware of them.

\subsubsection{Level of satisfaction}

Respondents were asked to indicate their level of satisfaction regarding the service provided number of collection and variety of information sources in a three point scale of satisfactory, fair and unsatisfactory.

Table 3.4 Level of satisfaction

\begin{tabular}{|c|c|c|c|c|c|}
\hline Sl.no. & Details & Satisfactory & Fair & Unsatisfactory & Total \\
\hline 1. & Service Provided & $\begin{array}{c}51 \\
(10.85 \%)\end{array}$ & $\begin{array}{c}187 \\
(39.79 \%)\end{array}$ & $\begin{array}{c}232 \\
(49.36 \%)\end{array}$ & 470 \\
\hline 2. & No. Of Collection & $\begin{array}{c}66 \\
(14.04 \%)\end{array}$ & $292(62.13 \%)$ & $\begin{array}{c}112 \\
(23.83 \%)\end{array}$ & 470 \\
\hline 3. & Variety of Information & $\begin{array}{c}85 \\
(18.05 \%)\end{array}$ & $\begin{array}{c}289 \\
(61.49 \%)\end{array}$ & $\begin{array}{c}96 \\
(20.43 \%)\end{array}$ & 470 \\
\hline
\end{tabular}

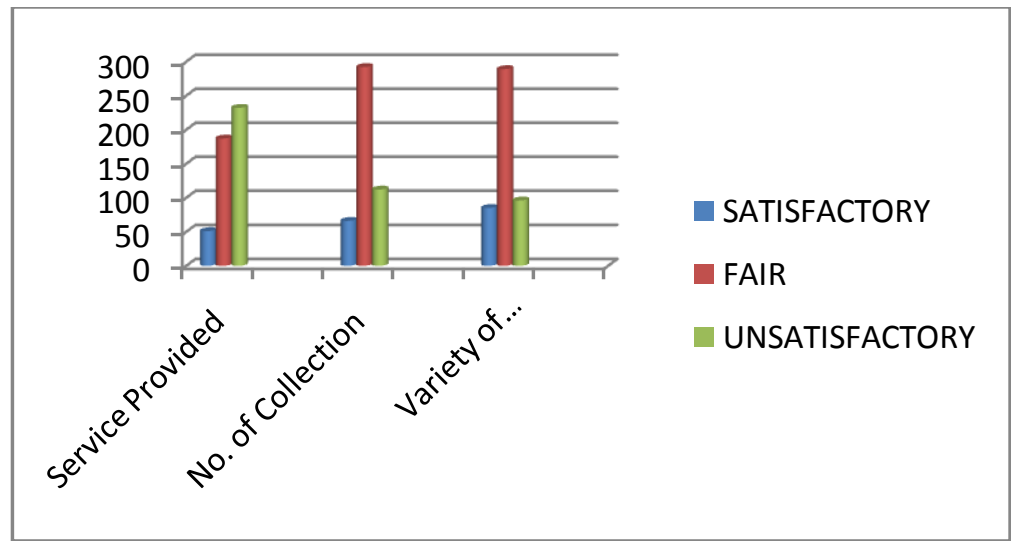

Fig.3.4 showing levels of satisfaction of the users 
The above table and fig. indicates the levels of satisfaction of the respondents regarding service provided, number of collection and variety of information. Analysis shows that $51(10.85 \%), 66(14.04 \%)$ and $85(18.05 \%)$ of the users are satisfied with the service provided by the library, the number of collection and variety of information available in the library. 187 (39.79\%), $292(62.13 \%)$ and 289 (61.49\%)of the users have rated fair for the services provided, number of collection and variety of information respectively. $232(49.36 \%), 112(23.83 \%)$ and $96(20.43 \%)$ rated unsatisfactory for the service provided, number of collection and variety of information available in the library.

\subsubsection{Reasons of dissatisfaction}

In order to find out the reasons of dissatisfaction 5 options such as information not up-to-date, information incomplete, service not prompt, insufficient library service, irrelevant information etc. were given for the users to rate.

Table 3.5 Reasons of dissatisfaction

\begin{tabular}{|c|c|c|c|}
\hline Sl. no. & Reasons & $\begin{array}{c}\text { No. of } \\
\text { responses }\end{array}$ & Percentage \\
\hline 1. & Information not up-to-date & 288 & $61.28 \%$ \\
\hline 2. & Information incomplete & 421 & $85.57 \%$ \\
\hline 3. & Service not prompt & 139 & $29.57 \%$ \\
\hline 4. & $\begin{array}{c}\text { Library service } \\
\text { insufficient }\end{array}$ & 389 & $82.66 \%$ \\
\hline 5. & Irrelevant information & 107 & $22.77 \%$ \\
\hline
\end{tabular}

Source: Primary Data

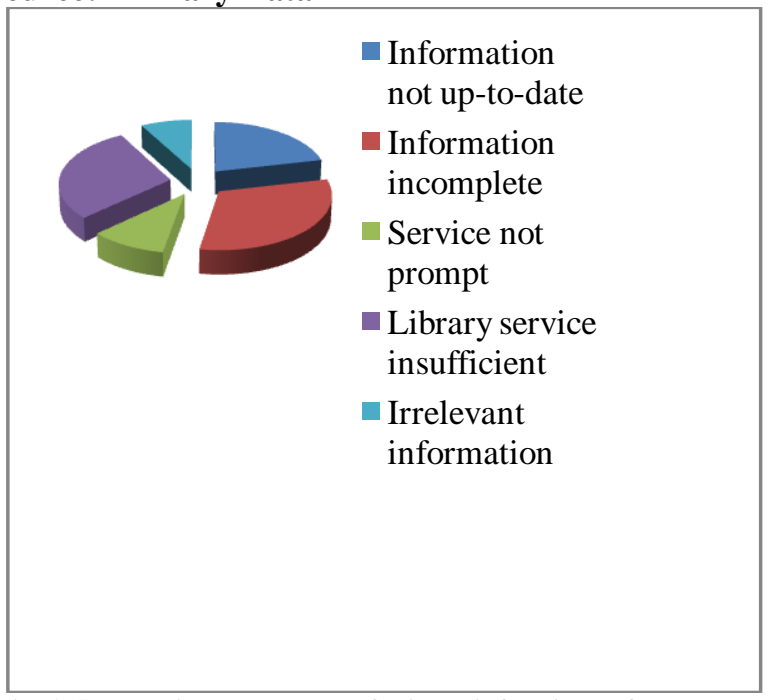

Fig.3.5 showing reasons of dissatisfaction of the users

As it is evident from Table 3.5 and Fig.3.5 that maximum users-421 (85.57\%) were dissatisfied due to incomplete information followed by $389(82.66 \%)$ users who were dissatisfied due to insufficient library services. $288(61.28 \%)$ of the respondents felt that information available were not up-to-date.139 $(29.57 \%)$ were dissatisfied as they did not get prompt library services. And $107(22.77 \%)$ found irrelevant information within the available resources of the library.

\subsection{Constraints faced by the users}

Information explosion and tremendous increase in publication has resulted in the increase of literature in leaps and bounds which is presumed to satisfy the information needs and information seeking behavior of different readers. But in reality, it is seen that the readers, at higher levels of education is left in ignorance, dilemma or confusion as to what to read, where to get it and how to get it. And in doing so, they come across many barriers and constraints which seriously affect their information seeking process.

\section{4 .1 information barrier constraints}

Information is accessed by the users, not only of their own, but also with the help of others. In order to understand as to why they face difficulty in accessing the information, probable factors such as 'lack of time', 'lack of access to all information', 'lack of reading materials', 'lack of knowledge of 
information sources', 'lack of knowledge in use of library services' and 'unfriendly library staffs' were listed as the difficulties. The feedback of the users in this respect was drawn out.

Table 4.1 Difficulties faced by the users

\begin{tabular}{|c|l|c|c|}
\hline SL.NO. & DIFFICULTIES & NO. OF RESPONSES & PERCENTAGE \\
\hline 1. & Lack of time & 167 & $35.53 \%$ \\
\hline 2. & $\begin{array}{l}\text { Lack of access to all } \\
\text { information }\end{array}$ & 323 & $68.72 \%$ \\
\hline 3. & Lack of reading materials & 318 & $67.66 \%$ \\
\hline 4. & $\begin{array}{l}\text { Lack of knowledge of } \\
\text { information sources }\end{array}$ & 196 & $41.70 \%$ \\
\hline 5. & $\begin{array}{l}\text { Lack of knowledge in use of } \\
\text { library service }\end{array}$ & 155 & $32.98 \%$ \\
\hline 6. & Unfriendly library staff & 49 & $10.43 \%$ \\
\hline
\end{tabular}

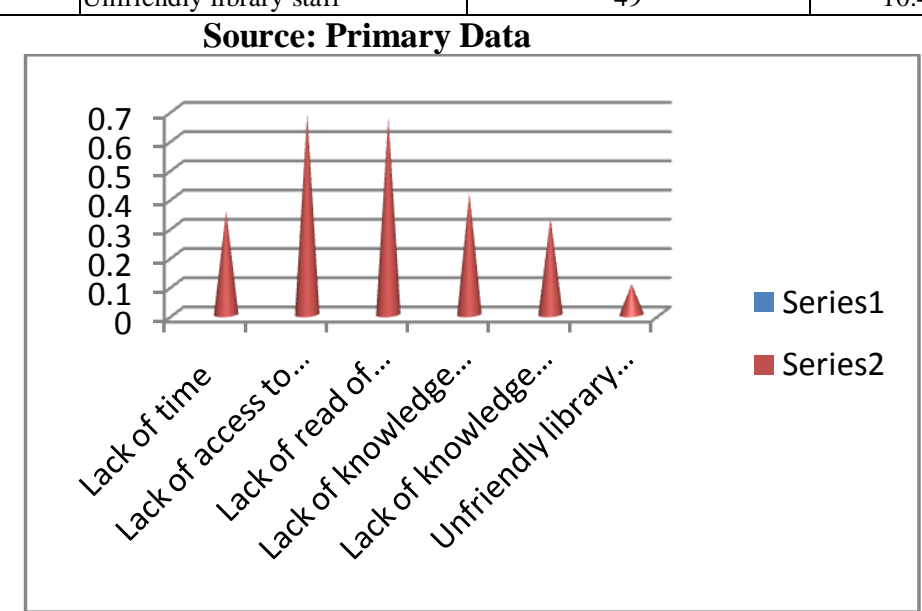

Fig.4.1 showing percentage of responses regarding the constraints faced by the users

Table 4.1 \& Fig.4.1 clearly shows that $323(68.72 \%$ ) respondents faced the problem of access to all information followed by $318(67.66 \%)$ of the users who found reading materials insufficient. $196(41.70 \%)$ of the users faces the problem due to lack of knowledge of information sources. $167(35.53 \%)$ of the users have difficulty in visiting the library and search information due to lack of time. $155(32.98 \%)$ faced problem due to lack of knowledge in the use of library services. The least number of users i.e. 49 (10.43\%) faced difficulties due to unfriendly library staffs.

\subsection{Suggestions from the users}

Suggestions from the users are always welcome as it is necessary to improve the resources and services of the library and sort out the possible constraints and difficulties faced by them. Analysis of the questionnaire showed that the users faced problems in collecting information in their field of study due to multiple factors, which deserve consideration and probable solution. The suggestions provided by them may be summarized as follows:

The University Library timing should be extended and kept open during holidays so that users can extensively use the library sources and services which are not possible due to their busy schedule. Latest editions and multiple copies of textbooks should be purchased and shelved within short period of time so that users can access them. Faculty members pointed out that there is a gap of almost a year between the purchase of books and shelving them. Most of the faculty members suggested regular shelf reading by the library staff which will enable to locate misplaced books and proper arrangement of books in the shelves. Due to the incomplete card catalogues and absence of online public access catalogues users face great difficulty in locating documents. Hence almost all respondents suggested for catalogues either in the card form or online. Library automation is thus the need of the hour which is also suggested by many users. Faculty members and research scholars suggested subscribing more national and international journals of importance for all subject fields and also pointed out that journals should be subscribed timely so that latest issues are available. Suggestions were made to start a back volume section of the journals so that retrospective search is possible. Almost all the users are dissatisfied with the Internet service of the library and suggested high speed internet connectivity. Also to solve the problem of power cut the respondents suggested procuring a generator for the library. Another suggestion was to increase the number of computers so as to fully utilize the e-resources of the library. Faculty Members suggested that awareness and training programs regarding use of information sources, library services and e-resources should be conducted from time to time. The users should be made aware of the e-journals available so that maximum utilization is 
possible. Though few respondents were aware of Current Awareness Service, Selective Dissemination of Information Service and Document Delivery Service, most of them were unaware of these services. So the respondents suggested for the wide publicity of the availability and use of such services.

\section{Findings Of The Study}

The findings of the study can be summarized as follows:

Maximum responses were received from the postgraduate students followed by undergraduate students and minimum responses were received from the non teaching staff. Also respondents of age 55 and above rarely visited the libraries. Female respondents were more compared to male respondents. In rating the extent of study/research/teaching needs met by the collection of the library textbooks, encyclopedia, periodicals, theses/dissertation and reference books were found to be partially adequate by maximum users. Dictionaries were found to be adequate by most of the users. Internet and e-journals were found to be inadequate by maximum users. Audio-visual sources i.e. television were found to be most popular for all the respondents followed by Internet, E-mail, CD-ROMs and Online Databases. Use of internet facility of the library was found to be very low and maximum responses of the users were negative. About $50 \%$ of the users were partially successful, about one-fourth of the users were successful and less than one-fourth of the users failed to get relevant information. Maximum respondents visited the library once a week followed by users visiting library twice a week, fortnightly and almost daily. Maximum respondents visit the library to borrow books, study/teaching/research and to locate information from documents. Less number visit the library to search information from e-resources and to spent leisure time. Regarding use of library services maximum respondents use circulation service followed by reprographic service and newspapers, magazines and journals service. Internet service is used the least followed by reference service. Although few respondents are aware of SDI, CAS and DDS but the use of these services are nil. Maximum users find the library service unsatisfactory, number of collection fair and variety of information satisfactory. Maximum users indicated that information available were incomplete and not up-to-date. Also library services provided were not sufficient. Regarding constraints faced by the users, maximum users found lack of access to all information and lack of reading materials. Many pointed out lack of knowledge of information sources, lack of time and lack of knowledge of use of library services as the constraints faced by them while accessing information. Some of the respondents pointed out the unfriendly behavior of the library staff. Most of the users pointed out considerable problem in locating suitable sources of interest.

\section{Conclusion}

The present study clearly indicates the multifarious information needs of the users. The study also revealed the information seeking behavior of the users under study which is influenced to some extent on the availability of information sources and the constraints faced by them in seeking information. The busy schedule of the users does not allow them to explore the library resources extensively; hence extended hours of library service may increase the use of the library. Also proper organization and maintenance of the collection, proper shelve guides; catalogs etc. will help the users in locating the information source thereby saving their valuable time. Most of the users indicated that they do not find latest editions of documents. By timely processing and shelving the procured documents this problem can be solved. Periodicals are one of the most important resources of the library which keeps the users abreast in their field of interest. Thus majority of the users suggested subscription of more national and international journals and back volumes to be maintained for retrospective search especially in the field of social sciences and humanities. Due to the publication explosion and sky high subscription rates of periodicals dependency on e-journals should be increased. Many Journals are available online through open access, networks and consortia. Users should be made aware of these e-journals and proper guidance should be given for their extensive use. The users should also be made aware of the different services available in the library and additional services should be introduced to increase the use of library. More professional and skilled staffs should be recruited to handle the day to day problems of the library and to provide efficient and smooth library services to the users. Internet facility should be improved along with increase in computer terminals so that more users can access the e-resources. The most important step to be taken by Assam University Library is Library automation which is the need of the hour so that users are in a position to access electronic bibliographic finding aids and databases and automation of all the sections of the library will enable its smooth and efficient functioning. Assam University Library has a long way to go in improving its resources and services and it is believed that it will soon be an important centre of learning not only for the University but also for the whole North East. 


\section{References}

[1] Anderson, B, Delivering career and job information: a place for libraries. Reference Librarian, 36, 1992, 17-32.

[2] Hoshvosky, A.G, Information Source: Its ends, means and opportunities. Information Transfer: Proceeding ASAS, 55(2), 1968, 47-55.

[3] Durrance, J.C. et al..., Serving job seekers and career changers: a planning manual for public libraries: part of public library development program (Chicago: American Library Association, 1993)

[4] Wilson, T.D, Models in information behavior research, Journal of Documentation, 55(3), 1999, 249-270

[5] Voigt, M.J, Scientists approach to information. (Chicago: ALA, 1961).

[6] Raj Rani , Information needs and the use pattern of journals in economics in the University of Jammu Library: a users' Survey. In: $49^{\text {th }}$ ILA Conference on "Responding to user's need in changing information landscapes: sojourn of libraries from palm leaf to palm top". Bundelkhand University. Jhansi, U.P. December 29, 2003-January 1, 2004.

[7] Nazim \& Saraf, S, Information searching habits of internet users: a users' study of Banaras Hindu University. Annals of Library and Information Studies, 53(4), 2006,213-218.

[8] Keshava \& Savanur, K, Information needs and information seeking strategies of agricultural scientists. In: $49^{\text {th }}$ ILA Conference on "Responding to user's need in changing information landscapes: sojourn of libraries from palm leaf to palm top". Bundelkhand University. Jhansi, U.P. December 29, 2003-January 1, 2004.

[9] Singh, K.P. \&Satija, M.P. (2007). Information seeking behavior of agricultural scientists with particular reference to their information seeking strategies.Annals of Library and Information Studies, 54, 2007, 213-220.

[10] Choukhande, V.G. (2008). Information needs and information seeking behavior. (Amravati: Shivneri Publisher,2008).

[11] Fatima, N. \& A.hmad, N, Information seeking behavior of the students at Ajmal Khan Tibbiya College, Aligarh Muslim University: a survey. Annals of Library and Information Studies, 55, 2008, 141-144.

[12] Devendra Kumar. (2009). Information needs of faculty members and research scholars of Chaudhary Charan Singh University: a case study. Library Philosophy and Practice, 2009, 1-7. Retrieved February 23, 2010 from http://unlib.unl.edu/LPP/kumar.htm.

[13] Mahajan, P, Information seeking behavior: a study of Panjab University, India. Library Philosophy and Practice, $2009,1-7$. Retrieved February 23, 2010 from http://unlib.unl.edu/Lpp/mahajan4.htm

[14] Ray, S.S. \& Balsy, M.D. (2010).Information seeking behavior of the academics of university library environment, IASLIC Bulletin, 55(4), 2010, 244-256.

[15 ] Jayaram, S., Subramanian, B. \& Krishnaswamy, N, Information needs and Information seeking behavior of students in Karpagam University: a survey.Library Progress (International),31(2), 2011,181-187.

[16] Junni, P. Students, Students seeking information for their Master's theses: the effect of the internet. IR Information Research, 12(2), 2007, 1-18, Retrieved April 30, 2013 from information.net/ir/12-2/paper 305.html.

[17] Nnadozie, C.O \&Nnadozie, C.D, The Information needs of faculty members in a Nigerian Private University: a self study. Library Philosophy and Practice, 2008, 1-10, Retrieved July 30, 2011 from http://unlib.unl.edu/LPP/nnadozie-nnadozie.htm

[18] Tahir, M., Mahmood, K. \& Shafique, F, Information needs and information-seeking behavior of arts and humanities teachers: a survey of the University of Punjab, Lahore, Pakistan. Library Philosophy and Practice, 2008, 1-12.,Retrieved February 23, 2010 from http://unlib.unl.edu/LPP/tahir-mahmmod-shafique.htm

[19] http://www.aus.ac.in/AUS-Prospectus-2011-2012.pdf

[20] Assam University, Annual Reports, 1994-2012 